\title{
New evidence for a glacioeustatic influence on deep water circulation, bottom water ventilation and primary productivity in the South China Sea
}

\author{
L. Löwemark ${ }^{\mathrm{a}, \mathrm{g}, *}$, S. Steinke ${ }^{\mathrm{b}}$, C.-H. Wang ${ }^{\mathrm{c}}$, M.-T. Chen $^{\mathrm{d}}$, A. Müller ${ }^{\mathrm{e}}$, \\ L.-J. Shiau ${ }^{\text {d, S.-J. Kao }}{ }^{\text {f }, ~ S .-R . ~ S o n g ~}{ }^{g}$, H.-L. Lin ${ }^{\text {h}}$, K.-Y. Wei ${ }^{g}$ \\ a Department of Geology and Geochemistry, Stockholm University, 10691 Stockholm, Sweden \\ b MARUM - Zentrum für Marine Umweltwissenschaften, Fachbereich Geowissenschaften, Universität Bremen, \\ Postfach 3304 40, D-28334 Bremen, Germany \\ c Institute of Earth Sciences, Academia Sinica, P.O. Box 1-55, Nankang, Taipei 115, Taiwan \\ d Institute of Applied Geosciences, National Taiwan Ocean University, 2 Pei-Ning Road, Keelung 20224, Taiwan \\ e Brisbane, Australia \\ ${ }^{\mathrm{f}}$ Research Center for Environmental Changes, Academia Sinica, Nankang, Taipei 115, Taiwan \\ ${ }^{g}$ Department of Geosciences, National Taiwan University, P.O. Box 13-318, Taipei 106, Taiwan \\ ${ }^{\mathrm{h}}$ Institute of Marine Geology and Chemistry, National Sun Yat-Sen University, Kaoshiung 804, Taiwan, ROC
}

\section{A R T I C L E I N F O}

\section{Article history:}

Available online 12 September 2008

Keywords:

Bottom water oxygen depletion

South China Sea

Productivity

Organic carbon preservation

Sea level

Monsoon

\section{A B S T R A C T}

We provide new evidence for the development of a stable estuarine circulation characterized by stagnating water bodies, nutrient recycling and increased primary productivity in the South China Sea (SCS) during glacial intervals. This circulation was caused by the closure of the shallow and narrow straits connecting the SCS in the south and west. Our main evidence is derived from newly measured Mn concentrations and $\mathrm{Mn} / \mathrm{Al}$ ratios in two sediment cores from the northern and southeastern SCS covering the last $500 \mathrm{ky}$. Concentrations and $\mathrm{Mn} / \mathrm{Al}$ ratios of the redox sensitive element Mn show clear glacial-interglacial cycles with maxima during interglacial periods and minima during glacial periods. These cycles indicate ventilation cycles of the bottom water, and are connected to the glacial-interglacial changes in sea level. In contrast, total organic carbon (TOC) concentrations display an opposite pattern with pronounced maxima during glacial times, especially in the southern part of the basin. The variations in TOC can be ascribed to two factors. Firstly, variations in primary productivity are controlled by variations in the intensity of the winter monsoon. Secondly to the degree of preservation of TOC controlled by variations in ventilation, which in turn is ultimately controlled by sea level.

\footnotetext{
* Corresponding author.

E-mail address: loewemark@gmail.com (L. Löwemark).
} 
Consequently, variations in TOC represent a superimposition of primarily sea level influenced preservation control and winter monsoon driven variations in primary productivity intensity. The decrease in Mn correspond to times when sea level dropped 40-60 $\mathrm{m}$ below the present level. The larger amplitude of the variations in TOC and Mn in the southern part of the basin compared to the northern site suggest that oxygen depletion and nutrient recycling was stronger in the parts of the basin situated the furthest away from the only remaining opening to the open Pacific, the Luzon Strait.

(c) 2008 Elsevier B.V. All rights reserved.

\section{Introduction}

The generally high sedimentation rates, good preservation of calcareous microfossils, and the position of the South China Sea (SCS) as a connector between two of the major engines in the global climate system: the Western Pacific Warm Pool and the SE Asian monsoon, makes the sediments of the SCS an ideal recorder of climatic change on millennial and orbital time scales. Marine records from the SCS therefore have often been used to reconstruct many aspects of both the regional and global paleoclimate system (e.g., Chen and Huang, 1998; Chen et al., 2003; Jian et al., 2000; Kienast et al., 2001a; Steinke et al., 2001; Wei et al., 2006b, 2003). Previous studies have suggested a strong winter monsoon control on primary productivity (Chen et al., 2003) and that deep waters in the SCS became poorly oxygenated due to increased primary productivity and restricted circulation during glacial periods (Wang et al., 1999). In contrast, other studies indicated that deep waters remained in contact with the open Pacific (Lin, 2003; Wei et al., 2006a). However, interpreting proxy records from the SCS is far from straightforward as the basin is influenced by a number of interconnected factors such as winter and summer monsoon, movement of the intertropical convergence zone, and sea level changes, all factors with a strong influence on local and regional variability in sea surface temperature, salinity and primary productivity. On orbital time scales, the SE Asian monsoon system is primarily influenced by two main drivers, precessional variations in insolation (Kutzbach, 1981) and 100 ky cycles in ice volume (Chen and Huang, 1998; Tian et al., 2004).

The purpose of this study is to attempt a separation of sea level variations from the monsoon forcing and their influence on primary productivity and preservation of organic matter content in the sedimentary record. We use records of the redox sensitive element $\mathrm{Mn}$ from two different parts of the basin to study variations in deep water ventilation and the influence of deep water circulation on organic carbon preservation at two sites, one distal and one proximal to the only deep connection (Luzon Strait) with the Pacific Ocean. A profound understanding of the basic circulation patterns and how they have changed with time is essential for the understanding and interpretation of the paleoenvironmental proxies recorded in the SCS.

\section{The South China Sea-hydrologic setting}

Today, the SCS plays an important part in the global climate system through its role in the transfer of climate signals between the western Pacific and eastern Indian Ocean. It is a major component in the Indonesian Throughflow, thus influencing phenomena like El Niño and the Indian monsoon (Qu et al., 2005). The SCS is also a major moisture source for the summer monsoon rains that fall over the Indochinese Peninsula and southern China (Chang, 2004; Wang, 2006), and it is believed to play an important role as heat capacitor, storing and releasing heat between years to the western Pacific and the eastern Indian Ocean, thereby taking a central position in the monsoon system (Qu et al., 2006b).

The modern circulation in the SCS is strongly influenced by the seasonal shifts of the monsoon system. The monsoon system is driven primarily by the differential heating between the land and the oceans, and by the moisture transport, which stores and releases energy as it changes from the vapor to 

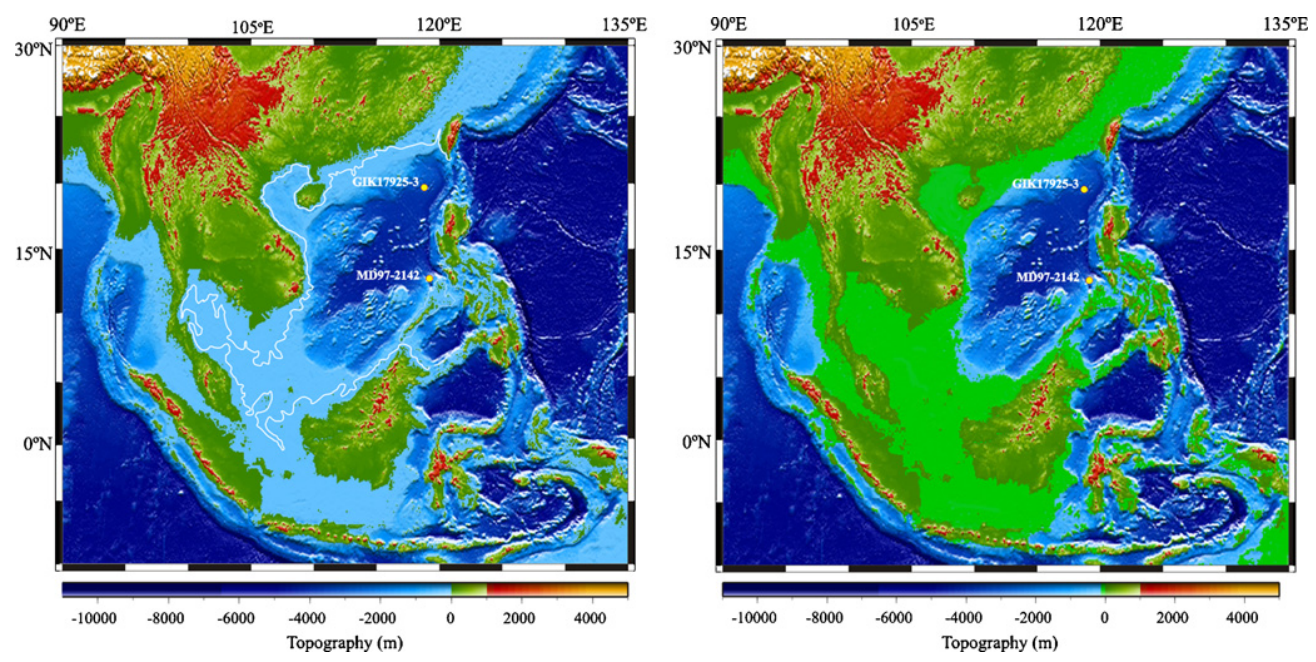

Fig. 1. Topographic maps showing the difference in basin configuration between interglacial sea level high-stand (left) and full glacial sea level low-stand (right) using a $120 \mathrm{~m}$ lowering of the shore line on modern topography. The comparison clearly displays the confined nature of the glacial basin and the exposure of the enormous shelf, particularly on the western side of the basin. The white isobath in the left panel shows the approximate position of the $50 \mathrm{~m}$ contour. The locations of the discussed cores are shown.

liquid state and back. The winter monsoon is caused by the rapid cooling of the Asian mainland while the ocean retains its heat longer, leading to a high-pressure cell over land and strong winter winds. These dry and relatively cold winds can reach as far as the southern part of the SCS where they are blocked by the Indonesian archipelago (Chang, 2004; Yamagata and Masumoto, 1989). In summer, the southwest monsoon drives an anticyclonic gyre in the southern part of the basin, while the winter surface water circulation is driven by the northeast monsoon causing a cyclonic gyre over the entire basin (Liang et al., 2000; Wyrtki, 1961). The summer monsoon results in upwelling and enhanced primary productivity off the east coast of Vietnam, while the winter monsoon causes upwelling northwest of Luzon and north of the Sunda Shelf (Liu et al., 2002). Surface sediment studies of the SCS reveal a general pattern of decreasing total organic carbon (TOC) content with increasing water depth (Calvert et al., 1993), which can be attributed to enhanced degradation in the longer water column and stronger degradation in the sediment caused by the generally lower sedimentation rates at deeper sites. There is also a trend of higher TOC levels in the sediments in the southern part of the basin compared to the northern part (Calvert et al., 1993).

The modern SCS intermediate and deep waters originate from the Pacific Intermediate Water entering through the Luzon strait, and the SCS deep waters are generally well-oxygenated due to their rapid renewal time (30-120 years) (Broecker et al., 1986; Gong et al., 1992; Qu et al., 2006a). In contrast, during glacial times the bottom waters in especially the southern part of the basin seems to have been affected by decreased oxygen levels in the bottom waters as inferred from benthic $\delta^{13} \mathrm{C}$ values and benthic foraminiferal assemblages. This is due to the combined effect of the development of a stable estuarine circulation and high fluxes of organic carbon (Jian et al., 1999; Wang et al., 1999). Even today, intermediate waters of the southern part of the SCS display a pronounced oxygen minimum at 700-1500 m water depth ( $\mathrm{Li}$ and $\mathrm{Qu}, 2006$ ), with the lowest values found in the southeastern corner of the basin (Qu, 2002). On glacial time scales the SCS is strongly influenced by changes in sea level caused by the waxing and waning of the continental ice sheets. During sea level high-stands the SCS is connected to the Indian and Pacific oceans through a number of narrow and shallow straits, which gradually close as sea level drops during the transition to glacial conditions, finally leaving only the about $2400 \mathrm{~m}$ deep Luzon Strait open as a major connection to the open ocean (Smith and Sandwell, 1997) (Fig. 1). 


\section{Materials and methods}

For this study two cores from the SCS were used (Fig. 1). Core MD97-2142 $\left(12^{\circ} 41.33^{\prime} \mathrm{N}, 119^{\circ} 27.90^{\prime} \mathrm{E}\right.$, $1557 \mathrm{~m}$ water depth) was retrieved at the continental slope off Palawan Island during the 1997 IMAGESIII-IPHIS Cruise (Chen and Beaufort, 1998). The total length of the core is almost $36 \mathrm{~m}$. The sediment at the coring site consists of fine-grained hemipelagic sediments with several intercalated tephra layers. The other piston core (GIK17925-3) was taken during the RV SONNE 95 cruise in 1994 (Sarnthein et al., 1994) on the northeastern slope of the SCS, less than $200 \mathrm{~km}$ from the Luzon Strait $\left(19^{\circ} 51.2^{\prime} \mathrm{N}\right.$, $119^{\circ} 28^{\prime} \mathrm{E}, 2980 \mathrm{~m}$ water depth). The core consist of hemipelagic muds and nannofossil oozes with some reworked ash layers. The spatial distribution of the studied cores enables a comparison of the conditions in the SCS close to, and far away from the only major opening to the open ocean during sea level low-stands.

For MD97-2142, TOC was measured using a HORIBA EMIA-8200 carbon analyzer at National Taiwan Ocean University (Chen et al., 2003) while the TOC from GIK17925-3 was obtained using a LECO CS-244 carbon/sulphur analyzer at the National Sun Yat-Sen University, Kaohsiung. The sedimentary TOC is often used as a first approximation to study changes in productivity and/or variations in the supply of terrigenous organic material. The $\delta^{13} \mathrm{C}$ of organic matter $\left(\delta^{13} \mathrm{C}_{\mathrm{org}}\right)$ in core MD97-2142 was measured using standard procedures (Boutton, 1991b) on a VG SIRA 10 mass spectrometer at Academia Sinica. The $\delta^{13} \mathrm{C}$ of the organic matter was measured in order to determine the origin of the organic material. Since the isotopic composition $\left(\delta^{13} \mathrm{C}_{\mathrm{org}}\right)$ of marine and terrigenous (C3-plants) organic matter is sufficiently different (ca. $-20 \%$ o for marine and ca. $-27 \%$ o for terrigenous (C3-plants)), the isotopic composition of the organic material allows an assessment of the relative proportion of both end-members (Boutton, 1991a).

Manganese contents in the cores were measured using a RIGAKU RIX2000 X-ray fluorescence spectrometer at the Department of Geosciences at National Taiwan University. While the sediment from GIK17925-3 where heated to $950^{\circ} \mathrm{C}$ to remove carbon and sulphur, the sediment from MD97-2142 was measured without this pretreatment. To account for the difference in treatment, element concentrations in GIK17925-3 where corrected for the material lost during ignition. Element concentrations often mirror variations in carbonate content, i.e. they are a function of variations in the input of terrestrial material vs. carbonate production. Following Brumsack (2006), we therefore also present Mn normalized to $\mathrm{Al}$ in order to be able to evaluate relative changes in $\mathrm{Mn}$. The redox sensitive element $\mathrm{Mn}$ is to be used as indicator of variations in the oxygenation of the bottom water. During times of anoxic or dysoxic conditions Mn would be expected to be leached from the sediment, while times of welloxygenated bottom waters are characterized by precipitation and deposition of Mn-rich sediments (Calvert et al., 1993; Wehausen et al., 2003).

The age model for core MD97-2142 was adapted from Wei et al. (2003) and is based on five AMS ${ }^{14} \mathrm{C}$-dates, and the correlation of stable oxygen isotopes (Globigerinoides ruber sensu stricto, white, $250-300 \mu \mathrm{m}$ ) with the low-latitude oxygen isotope stack of Bassinot et al. (1994). Additional age control points are the Brunhes-Matuyama magnetic polarity reversal at 776 ka (Lee, 2000), the last occurrence datum of pink G. ruber (125 ka) (Thompson et al., 1979), and the interval of Australasian microtektites (793 ka) (Lee and Wei, 2000) (Table 1). The age model for core GIK17925-3 was adopted from Löwemark et al. (2006) and is based on two AMS ${ }^{14} \mathrm{C}$-dates and the correlation of the stable isotope curve (G. ruber, white, $315-400 \mu \mathrm{m}$ ) with isotope events from Martinson et al. (1987), Shackleton et al. (2003), and Bühring et al. (2004) (Table 2). Age uncertainties from correlation with orbitally tuned isotope records typically lie within 5-6 ky (Bradley, 1999).

\section{Results and discussion}

\subsection{Temporal variations in TOC}

Although there are differences both in the amplitude of the variations and in the short-term variability of the TOC, the studied cores show a general pattern of higher TOC values in glacial intervals, and lower values during interglacials (Fig. 2). In the northern core, GIK17925-3, this is only 
Table 1

Age points used to establish the age model for core MD97-2142

\begin{tabular}{|c|c|c|}
\hline Depth $(\mathrm{cm})$ & Age point & Age cal. Ka \\
\hline 1 & AMS 14C & 1 \\
\hline 69 & AMS $14 \mathrm{C}$ & 5 \\
\hline 145 & & 6 \\
\hline 201 & AMS 14C & 12 \\
\hline 225 & AMS $14 \mathrm{C}$ & 14 \\
\hline 241 & & 16 \\
\hline 297 & AMS 14C & 21 \\
\hline 425 & & 34 \\
\hline 601 & MIS 3.1 & 52 \\
\hline 675 & & 64 \\
\hline 747 & MIS 5.1 & 80 \\
\hline 813 & & 94 \\
\hline 865 & MIS 5.4 & 106 \\
\hline 893 & MIS 5.5 & 122 \\
\hline 929 & MIS 6.0 & 128 \\
\hline 995 & & 136 \\
\hline 1034 & & 148 \\
\hline 1056 & & 156 \\
\hline 1104 & & 166 \\
\hline 1140 & & 176 \\
\hline 1172 & MIS 7.1 & 194 \\
\hline 1347 & MIS 7.3 & 214 \\
\hline 1379 & MIS 7.4 & 224 \\
\hline 1419 & & 234 \\
\hline 1493 & & 250 \\
\hline 1589 & MIS 8.4 & 266 \\
\hline 1663 & MIS 8.5 & 288 \\
\hline 1705 & MIS 8.6 & 296 \\
\hline 1778 & MIS 9.2 & 316 \\
\hline 1838 & MIS 9.3 & 328 \\
\hline 1896 & & 342 \\
\hline 1924 & MIS 10.3 & 348 \\
\hline 1974 & & 358 \\
\hline 2042 & MIS 11.1 & 370 \\
\hline 2090 & MIS 11.23 & 384 \\
\hline 2126 & & 392 \\
\hline 2221 & & 420 \\
\hline 2256 & MIS 12.2 & 434 \\
\hline 2284 & & 452 \\
\hline 2425 & MIS 13.11 & 482 \\
\hline 2441 & MIS 13.12 & 492 \\
\hline 2457 & MIS 13.13 & 500 \\
\hline 2489 & MIS 13.2 & 510 \\
\hline 2529 & MIS 13.3 & 524 \\
\hline
\end{tabular}

From Wei et al. (2003).

expressed as slightly raised values during glacial intervals MIS 2 and 10, while the southern core, MD97-2142, shows pronounced increases in TOC during glacial maxima. Core MD97-2142 also differs from core GIK17925-3 in that it has much stronger variability on shorter time scales. Especially in the upper part of the record, excursions over $0.5 \%$ on time scales of just a few thousand years are not uncommon. Spectral analysis of TOC (Chen et al., 2003, not shown) in core MD97-2142 show that the strongest variability occurs at the 100 ky eccentricity band, although distinct peaks are also present in the obliquity and precession bands. Core MD97-2142 also shows an extreme excursion during MIS 12 with values reaching over 1.5\%. Unfortunately, the northern record (GIK17925-3) does not reach this far back in time, preventing a direct comparison during this interesting time interval (Fig. 2). 
Table 2

Age points used to establish the age model for core GIK17925-3

\begin{tabular}{|c|c|c|}
\hline Depth cm & Age point & Age cal. (ka) \\
\hline 60 & Younger Dryas, top & $11.6^{¥}$ \\
\hline 105 & AMS & 13.9 \\
\hline 125 & AMS & 14.5 \\
\hline 130 & 2.2 & $18.0^{*}$ \\
\hline 255 & 3.3 & $55.5^{*}$ \\
\hline 270 & 4.2 & $65.0 ?^{*}$ \\
\hline 285 & 5.1 & $79.5^{*}$ \\
\hline 315 & 5.31 & $96.3^{*}$ \\
\hline 340 & 5.33 & $103.5^{*}$ \\
\hline 390 & 5.51 top & $116^{\dagger}$ \\
\hline 440 & 5.51 base & $126^{\dagger}$ \\
\hline 455 & 5.53 & $132^{\dagger}$ \\
\hline 500 & 6.2 & $136^{\dagger}$ \\
\hline 550 & 6.44 & $157^{¥}$ \\
\hline $560-620$ & 6.5 & $163-174^{¥}$ \\
\hline 660 & 6.6 base & $184^{¥}$ \\
\hline 670 & 7.1 top & $193^{¥}$ \\
\hline 710 & 7.3 & $215.5^{¥}$ \\
\hline 770 & 7.5 & $240.5^{¥}$ \\
\hline 800 & 8.02 & $247.5^{¥}$ \\
\hline 830 & 8.24 & $260.5^{¥}$ \\
\hline 850 & 8.4 & $267.5^{¥}$ \\
\hline 900 & 8.5 & $287.5^{¥}$ \\
\hline 930 & 8.6 & $294^{¥}$ \\
\hline 960 & 9.1 & $313^{¥}$ \\
\hline 1040 & 9.3 base & $330^{¥}$ \\
\hline 1095 & 11.1 & $368^{¥}$ \\
\hline 1190 & 11.3 & $418^{¥}$ \\
\hline 1210 & 12.2 & $426^{¥}$ \\
\hline
\end{tabular}

From Löwemark et al. (2006). Isotope event ages derived from *Martinson et al. (1987), ${ }^{\dagger}$ Shackleton et al. (2003), and ${ }^{\sharp}$ Bühring et al. (2004).

\subsubsection{Diagenesis and the degradation of organic carbon}

During burial, the organic carbon content in marine sediments is affected by diagenetic processes (Tyson, 1995). This raises the question of whether the observed TOC variations could be due to diagenetic alteration of the sediment? In a compilation of the results from a number of studies, Tyson (1995) showed that 63-98\% of the sedimentary organic carbon is relatively easily metabolized and is usually degraded or altered to refractory carbon by synsedimentary processes or during diagenesis. As most labile carbon is remineralized within a few years to a couple of thousand years in near surface sediments, the geological importance of labile carbon is that it consumes oxygen in the water column and in the pore water, creating conditions favorable of preserving refractory carbon that requires oxygen for its degradation. Consequently, once the sediment reaches a depth below $0.5-2 \mathrm{~m}$ below the sediment surface, TOC values are not significantly altered by degradation (Tyson, 1995).

\subsubsection{TOC and sedimentation rate}

In addition, the TOC of marine sediments is also influenced by variations in sedimentation rates. To what extent are the observed variations related to variations in sedimentation rate? A number of studies show a positive correlation between TOC and sediment accumulation rate (Tyson, 1995). However, sedimentation rate is only of importance when it varies by several orders of magnitude (Heath et al., 1977; Müller and Suess, 1979). Sediment accumulation rates of $0.1-1 \mathrm{~cm} \mathrm{ky}^{-1}$ have little influence on TOC preservation, and only at rates above $10 \mathrm{~cm} \mathrm{ky}^{-1}$ an effect may be noticeable (Emerson, 1985; Ingall and van Capellen, 1990). Actually, dilution of the organic matter by inorganic matter may quickly outstrip the potential increase in TOC preservation brought about by the faster burial, even at sedimentation rates as low as $<4 \mathrm{~cm} \mathrm{ky}^{-1}$ (Ibach, 1982; Tyson, 2001). Because increased sedimentation rate is also often coupled to increased carbonate flux, which in its turn is coupled to primary 

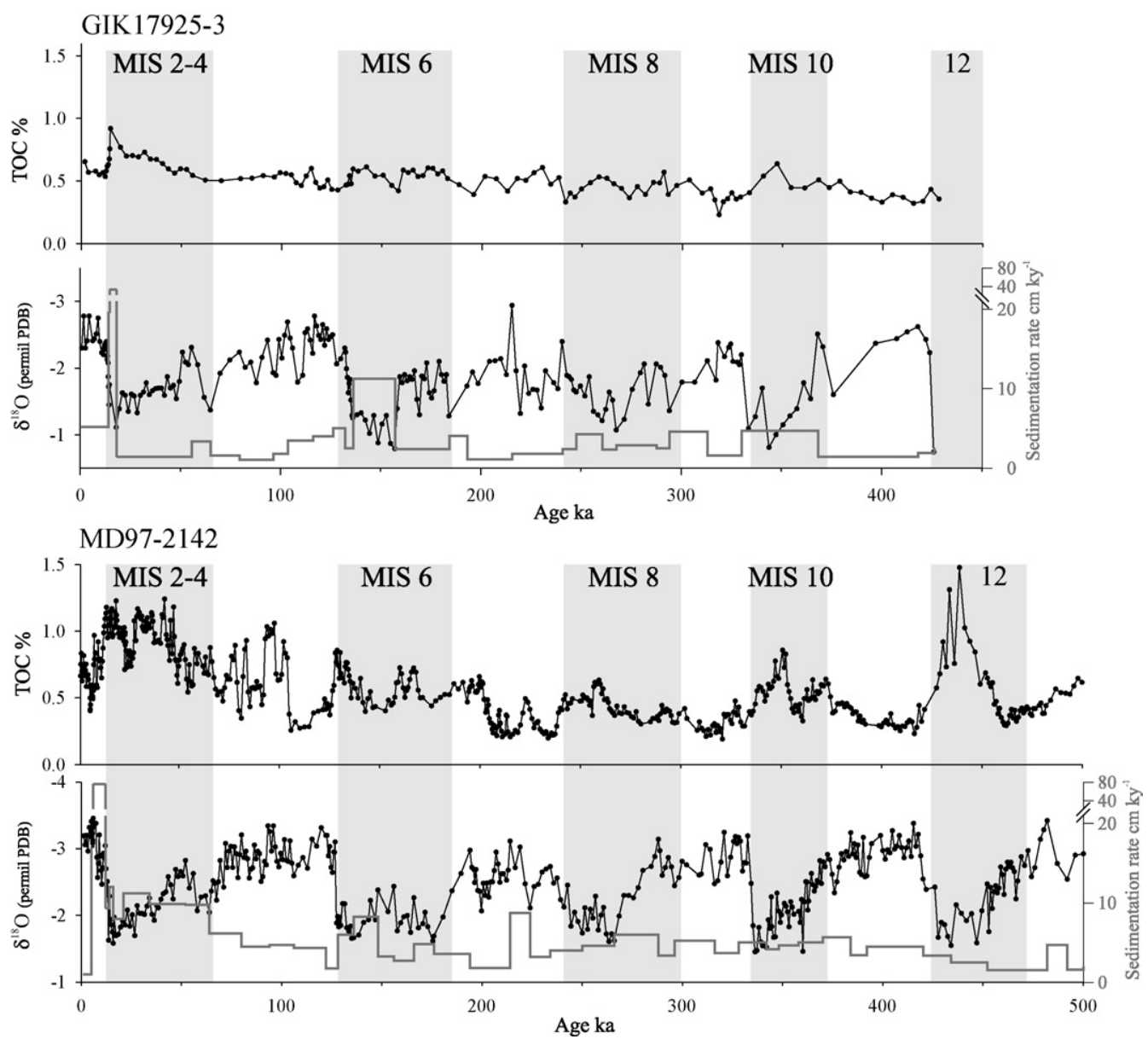

Fig. 2. Stable oxygen isotope stratigraphy, TOC and sedimentation rate. Both cores show a glacial-interglacial cyclicity in TOC but the amplitude is considerably larger in the southeastern core.

productivity, there is a positive coupling between sedimentation rate and TOC, and this coupling is not directly related to preservation (Betzer et al., 1984). In the SCS, however, fluctuations in carbonate content are clearly related to dilution by terrestrial sediment (Chen et al., 2003; Zhao et al., 2006). No correlation between TOC and sedimentation rate was observed (Fig. 3), suggesting that variations in sedimentation rate is not the underlying cause for the large fluctuations observed in the southern core.

\subsubsection{Marine vs. terrestrial origin of the organic matter}

A central question is of course whether or not the peaks in TOC are of marine or terrestrial origin. A marine origin would indicate increased primary productivity, while a terrestrial origin could be due to an increase in the input of terrestrial carbon caused by the direct proximity of the river mouths to the core locations due to a lowered sea level. The $\delta^{13} \mathrm{C}$ of organic material can be used to separate between marine and terrestrial sources, with values generally around $20 \%$ or for marine, and around $27 \%$ for terrestrial end-members (Boutton, 1991a). Measured $\delta^{13} \mathrm{C}_{\text {org }}$ values from MIS 12 through 10 in MD97-2142 show a clear glacial-interglacial variability with values around $-20 \%$ during glacials and around $-22 \%$ o during interglacials (Fig. 4). Similar shifts have also been observed elsewhere in the SCS (Kienast et al., 2001b; Thunell et al., 1992). If increased terrestrial input was responsible for the 

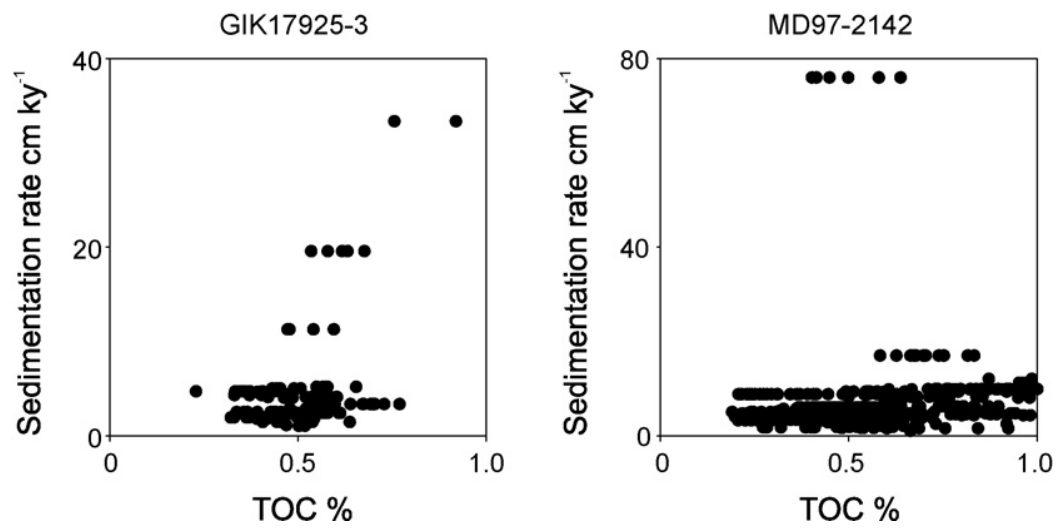

Fig. 3. Scatter plots of sedimentation rate vs. TOC for cores GIK17925-3 and MD97-2142. In both cores $\mathrm{R}^{2}$ is close to zero, corroborating the observation that there is no correlation between sedimentation rate and TOC.

increased TOC levels during glacials, then $\delta^{13} \mathrm{C}_{\text {org }}$ values would be expected to drop rather than increase during glacials, suggesting that the influence of terrestrial material in the observed TOC peaks is low. Hypothetically, a dramatic interglacial-glacial shift in the flora towards C4-plants with $\delta^{13} C_{\text {org }}$ values around $-14 \%$ o could lead to isotopically lighter values during glacials. However, today, vegetation on Palawan and nearby Philippine islands is dominated by tropical rain forest composed of C3-plants which generally have $\delta^{13} \mathrm{C}$ values around $-27 \%$, and pollen analysis of the last glacial-interglacial cycle show no major reorganization towards C4-plants (Sun et al., 1999; Whitmore, 1975). A marine origin of the organic material is also confirmed by a small number of $\mathrm{C} / \mathrm{N}$ measurements (S.-J. Kao, personal communication). Under any circumstance, C4-plants are more easily degraded than C3-plants, leading to an overrepresentation of C3-plant material in the sediment (Müller et al., 1983; Tyson, 1995), and even lesser likelihood of a C4-plant influence on the $\delta^{13} C_{\text {org }}$ signal. Although substantial input of terrestrial organic material has been observed in the slope sediments off the Sunda shelf in the southwestern SCS, the terrestrial influence rapidly decreased with increasing distance from the shelf (Steinke et al., 2003). Consequently the terrestrial influence should be small and the variations in $\delta^{13} \mathrm{C}_{\text {org }}$ are therefore interpreted to reflect changes in marine organic carbon rather than fluctuations in the input of terrestrial material.

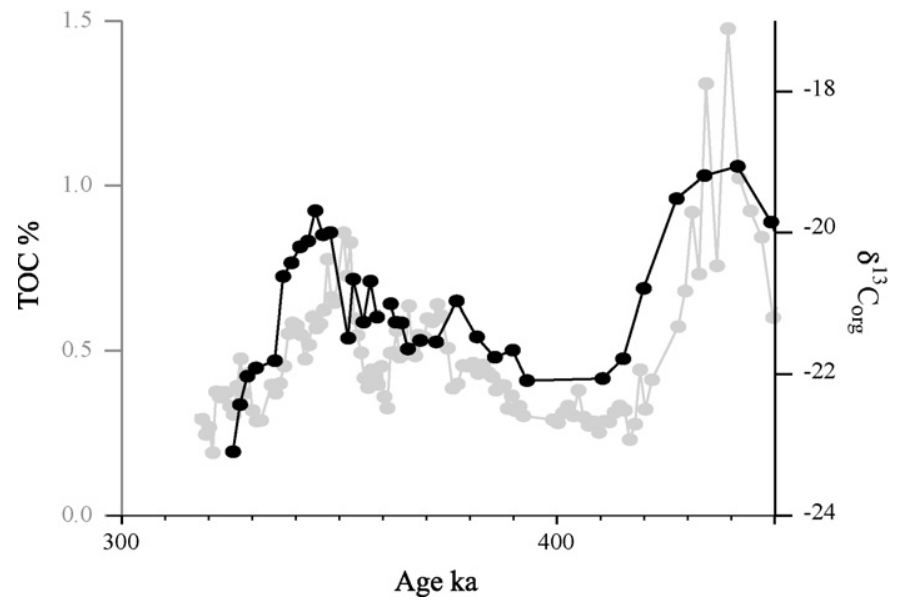

Fig. 4. TOC and $\delta^{13} \mathrm{C}_{\text {org }}$ covering marine isotope stages 12-10 in core MD97-2142 from the southeastern part of the basin. The heavier carbon isotopes found in the TOC peaks indicate that the increased TOC is caused by increased marine productivity. 
One argument against a marine origin of the organic carbon comes from studies of variations in $n$-nonacosane, used as an indicator for terrestrial carbon input (Pelejero, 2003). Four cores from the southern, western and northern SCS show a clear increase in terrestrial input during glacial times. However, although these records indicate a strong increase in the input of terrestrial $n$-nonacosane, this does not tell us how large the proportion of terrestrial TOC is in relation to the total TOC, which clearly is dominated by marine organic carbon.

It is well established that isotope fractionation in phytoplankton decreases as primary productivity increases, resulting in heavier (positive) $\delta^{13} \mathrm{C}_{\mathrm{org}}$ (Sarnthein et al., 1988; Tyson, 1995). For example, sediments deposited off West Africa during times of glacial upwelling were $2 \%$ heavier due to increased productivity compared to interglacial sediments (Müller et al., 1983). Consequently, the increased $\delta^{13} \mathrm{C}$ values in the TOC peaks show that they were caused by increased primary productivity. Another argument for a marine origin of the organic matter comes from a comparison of benthic $\delta^{13} \mathrm{C}$ from the SCS with the open Pacific (Wei et al., 2006a). This study showed that although the $\delta^{13} \mathrm{C}$ values in the SCS generally follow the open Pacific Ocean, indicating a continuous exchange between the water bodies, there is also an increase in the gradient between the oceans during the glacial intervals MIS 4 and 6. This increased gradient suggests an enhanced productivity coupled to sea level low-stands. Increased productivity in the SCS during glacial and stadial intervals is also supported by several studies showing increased TOC levels in various parts of the basin (e.g., Huang et al., 1997; Lin et al., 1999; Thunell et al., 1992). It has been argued that an intensification of the winter monsoon during glacial times would increase mixing and productivity (Higginson et al., 2003), and thus cause the observed increases in TOC (Chen et al., 2003).

Here it is important to note that the variability in TOC closely corresponds to the amplitude of insolation changes. During intervals of enhanced insolation variability, such as the interval from around MIS 7 to the Last Glacial Maximum, TOC variability show high frequency and high amplitude changes. In contrast, in the part of the record that is characterized by small insolation changes, the changes in TOC show a clear glacial cycle but only small higher-frequency variability. On longer time scales the winter monsoon is also influenced by ice volume changes through shifts in the position and/or strength of the Siberian high-pressure system (Chen and Huang, 1998; Ding et al., 1995). It has been previously found that the strength of the winter monsoon appears to be anticorrelated with the intensity of the summer monsoon (Wang et al., 1999; Wehausen and Brumsack, 2002; Yancheva et al., 2007). Strengthened winter monsoon winds during glacial times are also independently supported by $\delta^{18} \mathrm{O}$ records from the Sulu Sea. These records indicate that a freshening of the surface waters during glacial times was caused by the combination of lowered sea level and the inflow of SCS waters into the Sulu Sea forced by the enhanced winter monsoon winds (Oppo et al., 2003; Rosenthal et al., 2003). It is interesting to note that opal, considered to be a proxy for summer monsoon-induced productivity, displays maxima during interglacial, thus being in antiphase with the TOC records (Shiau et al., 2008). We therefore conclude that TOC in the sediment is primarily controlled by variations in the winter monsoon. In addition, the extreme TOC peaks observed during glacial maxima, in particular during MIS 12, 10 and 2, suggest that sea level changes also play an important role by changing the geometry from a well-connected basin to a semiconfined basin, where an estuarine circulation led to bottom water oxygen deficiency and recycling of nutrients in the basin as suggested by Tamburini et al. (2003). The conclusion that the SCS experienced oxygen deficiency in the deeper parts during sea level lowstands is corroborated by epibenthic $\delta^{13} \mathrm{C}$ values which show extremely light values during times of lowered sea level, indicative of enhanced primary productivity, oxygen-minima and/or possibly an estuarine circulation due to closure of the straits connecting the SCS to the open ocean (Wang et al., 1999).

Moreover, through end-member modeling Boulay et al. (2007) could show that during the past 900 ky grain size variability in the SCS is primarily controlled by sea level variations, and not by variations in eolian input as previously believed. This would agree with the idea that enhanced riverine input of nutrients directly to the central basin, combined with nutrient recycling under low-oxic conditions, play an important part in the control of primary productivity during sea level minima. The extreme TOC peak found in MIS 12 with TOC values well above $1.5 \%$ and $\delta^{13} \mathrm{C}_{\text {org }}$ values clearly indicative of strong biological pumping thus would be caused by an extreme sea level low-stand - the lowest in the last 500 ky (Waelbroeck et al., 2002) - enhancing nutrient recycling in combination with winter 

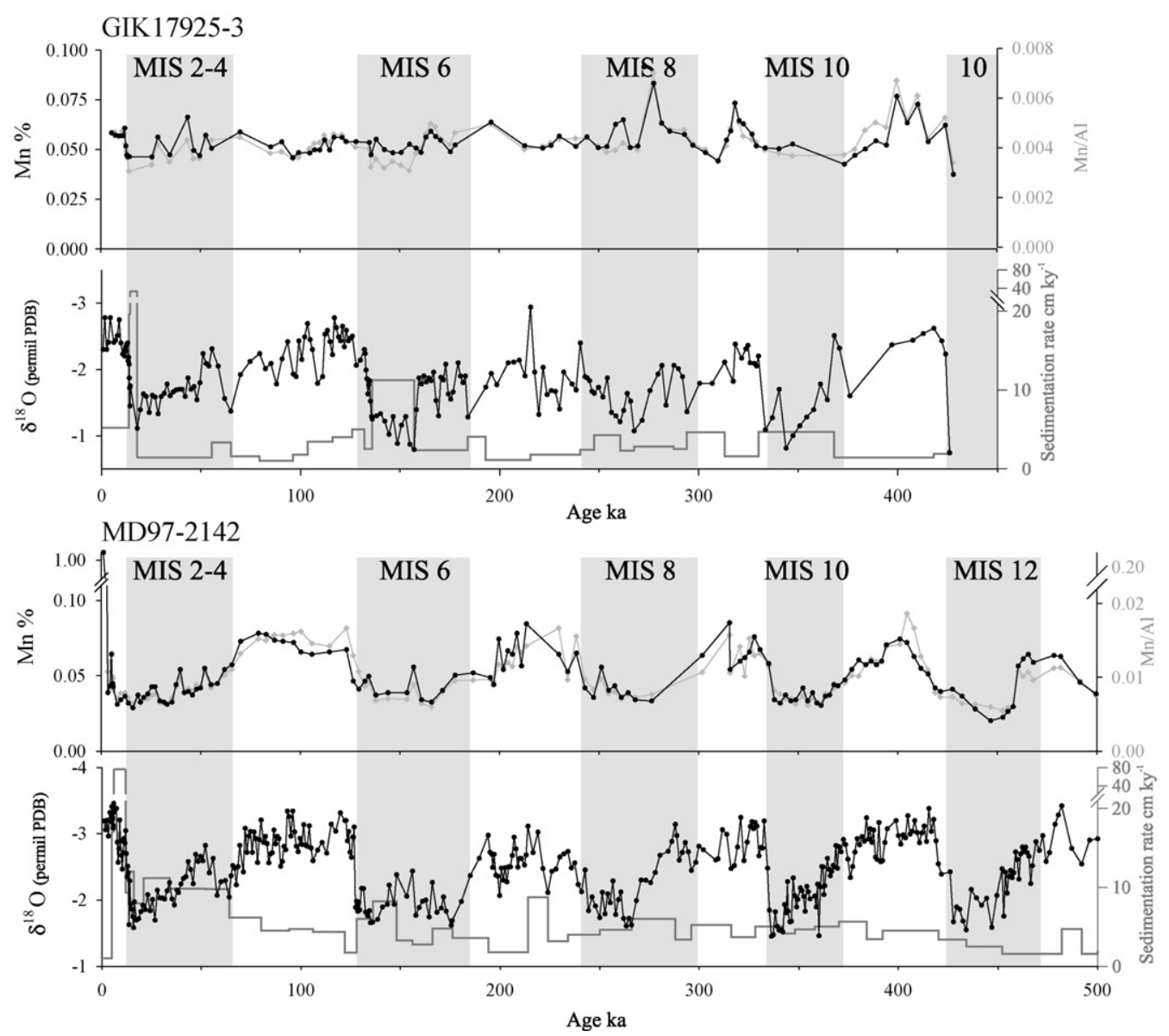

Fig. 5. Mn/Al-ratio and Mn content shown for the two studied cores from the South China Sea. Both cores show a glacial-interglacial cyclicity, but similar to the variations in TOC, the amplitude is considerable larger in the southeastern core.

monsoon winds enforced by the massive ice sheet build up that caused a pronounced shift in the Siberian high-pressure system.

\subsection{Temporal variations in manganese content}

Restricted ventilation, oxygen deficiency and nutrient recycling would be expected to leave a clear imprint in redox sensitive elements, such as $\mathrm{Mn}$, in the sedimentary record (Jakobsson et al., 2000; Löwemark et al., 2008; van Santvoort et al., 1996; Wehausen et al., 2003). We therefore present records of Mn from two cores from the northern and southeastern SCS. Mn concentrations, as well as the Mn to Al ratios, show a distinct glacial-interglacial pattern with maxima during interglacial periods, and generally low levels during glacial periods (Fig. 5). This pattern is most pronounced in the core situated in the southeastern part of the basin (MD97-2142) while the northern core (GIK17925-3) displays considerably lower amplitude variations and only minor peaks at interglacial intervals. Spectral analysis of the Mn records reveal a strong $100 \mathrm{ky}$ cycle in especially the southeastern core (Fig. 6). A similar pattern with increased Mn concentration during glacials was also observed in ODP core 1144 (Wei et al., 2004). This suggests considerably larger variability in the redox conditions of the bottom water in the southern part of the SCS compared to the northern part. 

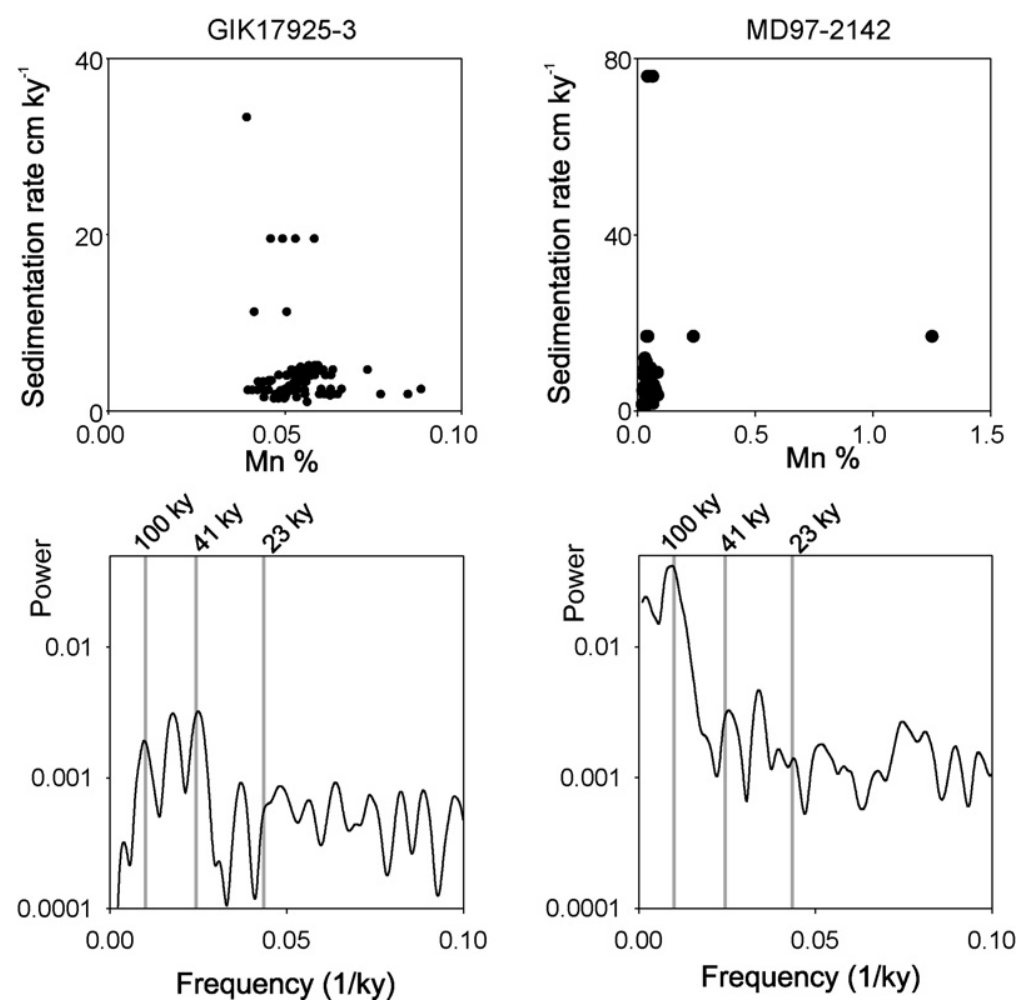

Fig. 6. Scatter plots and spectral analysis of Mn in the cores GIK17925-3 and MD97-2142. In the scatter plots of sedimentation rate vs. Mn the $\mathrm{R}^{2}$ is close to zero for both cores. This corroborates the observation that there is no correlation between sedimentation rate and TOC. Spectral analysis of Mn variability in the two cores show distinct maxima at the eccentricity and obliquity bands. While the 100 ky eccentricity cycle is rather weak in core GIK17925-3, it is the more pronounced in core MD97-2142, indicating that variations in $\mathrm{Mn}$ in the southeastern part of the basin are strongly influenced by ice volume changes.

In the marine environment, $90 \%$ of the Mn originates from hydrothermal activities on the sea floor (Schultz and Zabel, 2000), which show relatively little variability on shorter time scales. Therefore, variations in bulk Mn content could be due to three different processes: (1) diagenetic dissolution of Mn in the sediment and reprecipitation at another stratigraphic level, (2) fluctuations in terrestrial input of $\mathrm{Mn}$, and (3) variations in the intermediate and deep water ventilation resulting in alternating precipitation and leaching of $\mathrm{Mn}$ in the sediments. Could the observed Mn peaks be diagenetic, caused by dissolution of Mn under reducing conditions in the organic-rich part of the sediment, and subsequent upwards migration into overlying, well oxidized sediments? Diagenetic peaks of this type are not uncommon in marine sediments (Mangini et al., 2001), and the organic-rich intervals most likely provide sufficiently reducing conditions for mobilization of Mn. However, two arguments speak against diagenesis as the primary cause of the observed peaks. First, the Mn peaks are much broader than would be expected if they were caused by mobile Mn migrating towards a well-defined redox boundary near the top of the organic-rich layer. Second, the fact that distinct Mn peaks are found also in core GIK17925-3, where TOC variations are small suggest that they are formed by another process.

The $\mathrm{Mn}$ in the sediment could also be partially detrital, and have been brought into the basin by variations in delivery from the hinterland. However, increased trapping on shelves during sea level high-stands would be expected to result in minima rather than maxima. Wehausen et al. (2003) observed a similar pattern in late Pliocene to early Pleistocene sediments from the southwestern SCS with strongly increased $\mathrm{Mn} / \mathrm{Al}$ ratios during interglacials and depleted ratios during glacial intervals. They interpreted the increased Mn levels to be caused by increased mobilization of Mn on the 
shelves and continental margins. This was attributed to increased productivity and the development of oxygen minimum zones on the margins, favorable for leaching of Mn from shelf and margin sediments. Subsequently the leached Mn would have been transported into the well-oxygenated basin where it precipitated. This seems a somewhat awkward explanation for the observed Mn variations in this study as highest productivity is coupled to glacial/stadial conditions and sea level low-stands (Chen et al., 2003). The variability observed by Wehausen et al. (2003) appears to have been smaller before $\sim 2.7 \mathrm{Ma}$, when intense glaciations and consequently sea level variations commenced, indirectly lending support to the idea that Mn variations are controlled by sea level.

Studies of marginal seas such as the Celebes Sea, East China Sea or the Yellow Sea have shown that $\mathrm{Mn}$ is leached from the sediment and released to the bottom waters from sediment rich in organic matter and with reducing pore water conditions (Minakawa et al., 1996; Obata et al., 2007). In basins with anoxic water columns, such as the Cariaco Basin, $\mathrm{Mn}$ is remineralized already in the water column and thus the flux that reaches the sea floor is considerably decreased (Jacob et al., 1987). It therefore seems plausible that the glacial-interglacial variations observed are primarily reflecting changes in bottom and deep water ventilation caused by reorganization of the basin configuration in combination with variation in primary productivity. During glacial times the enclosed configuration of the SCS led to increased nutrient input to the central basin because the rivers emptied their load directly

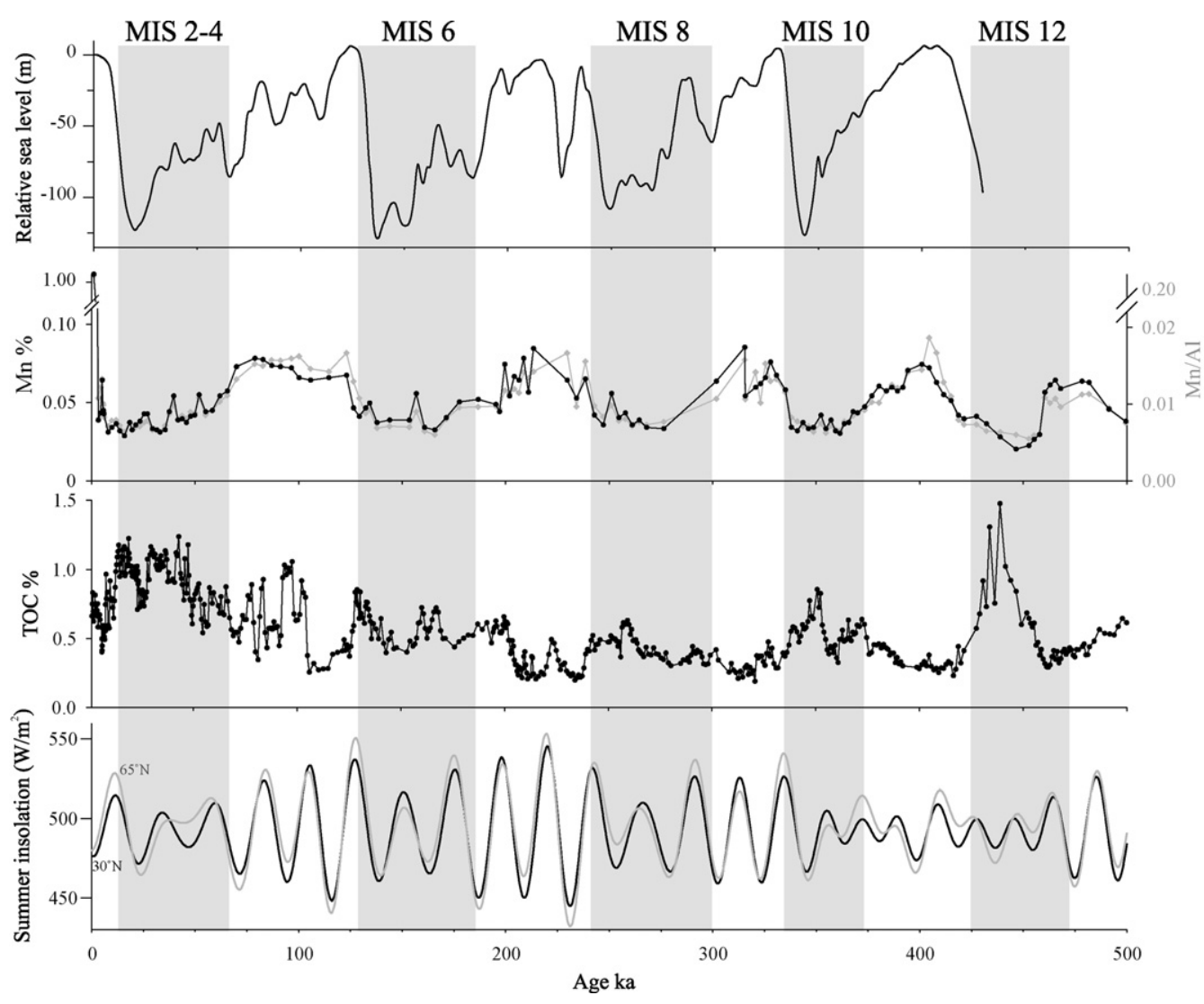

Fig. 7. Relative sea level variations (Waelbroeck et al., 2002), Mn and TOC values from MD97-2142, and summer insolation at $30^{\circ} \mathrm{N}$ (black line) and $65^{\circ} \mathrm{N}$ (gray line) (Laskar et al., 1993). Enhanced TOC levels generally correspond to sea level minima. Note that the variations in TOC show considerably larger amplitude during intervals of larger insolation variability, indicating the importance of precession and obliquity control on winter monsoon winds. Maxima in Mn occur once sea level rises above a threshold level around $40-60 \mathrm{~m}$ below the present day level. 
into the deep basin rather than onto the shelves. The closure of the shallow straits connecting the SCS in the south and in the west resulted in a restricted deep water circulation (Wang et al., 1999), which together with an increased productivity caused by stronger mixing related to the enhanced winter monsoon led to anoxic or dysoxic bottom and pore waters and recycling of nutrients within the basin. As a result, Mn was leached from the sediment during deposition, and this resulted in low Mn concentrations. Additionally, a sea level lowering during glacial times likely also caused a deepening of the oxygen-depleted layer that has been described for the modern SCS ( $\mathrm{Li}$ and Qu, 2006). Since core MD97-2142 is located just below the modern oxygen-depleted layer (ranging from ca. 700 to ca. $1500 \mathrm{~m}$ ), we speculate that a sea level lowering resulted in a shift of the intermediate waters to include the core position into the oxygen minimum zone during glacial periods. In contrast, the northern core (GIK17925-3) would constantly have been situated below this oxygen minimum zone, as reflected by both TOC and Mn values. Interglacial conditions were characterized by nutrient trapping on the shelves, weaker winter monsoon winds resulting in decreased primary productivity, a more open circulation and well-oxygenated bottom water conditions. As a consequence, Mn was deposited and preserved in the sediments. This scenario is in good agreement with the stable estuarine circulation proposed for glacial conditions as soon as sea level dropped more than 40 meters (Wang et al., 1999). In fact, Mn values show a distinct shift to low levels whenever the sea level dropped below 40-60 m, indicating that this level is a threshold for the formation of stagnating water bodies in the SCS (Fig. 7). Interestingly, the return to fully oxygenated bottom waters, as indicated by Mn maxima, does not seem to have taken place until sea level was close to present day levels (Hanebuth et al., 2000; Waelbroeck et al., 2002).

\section{Conclusions}

Organic carbon contents in sediments from the SCS display considerable temporal variability, with clear maxima during glacial stages, and minima during interglacial stages. Superimposed on these long-term changes, short-term variability on obliquity- and precession-time scales is present. These changes have been linked to sea level controlled variations in basin geometry and variability in the strength of the SE Asian winter monsoon winds (Chen et al., 2003). The relative importance of these two factors, however, has remained elusive. From detailed studies of variation in the redox sensitive element $\mathrm{Mn}$, and stable carbon isotopes of the organic matter, several conclusions can be drawn.

The $\delta^{13} \mathrm{C}$ values of the organic matter in the sediment strongly suggest a marine origin of the carbon, thus excluding the possibility that the increased TOC content during sea level low-stands was caused by increased terrigenous carbon input.

Variations in sedimentary Mn content show a strong 100 ky cyclicity and practically no variability in the precession and obliquity bands. This indicates that variations in Mn are closely connected to sea level controlled variations in bottom water ventilation rather than to variations in insolation and monsoon intensity.

Both Mn and TOC variability is considerably larger at the site that is situated the farthest from the Luzon Strait, the only remaining opening to the open ocean. This clearly indicates the importance of the exchange of intermediate Pacific waters for the ventilation of the northern part of the basin during glacial sea level low-stands.

These observations allow a qualitative separation of the effect of sea level from the effect of changes in monsoon strength on the TOC record in the SCS. In detail, we postulate a scenario where an icevolume controlled drop in sea level of about 40-60 m would close the straits connecting the SCS with the Indian Ocean and the other seas of the Indonesian archipelago. Such closure would have led to the development of a stable estuarine circulation and to the focusing of nutrients to the central basin through the shift of the river mouths closer to the shelf break. Reducing bottom water conditions along the slopes and in the deeper part of the basin would have developed as a consequence. The oxygendepleted bottom water conditions would then have assisted nutrient recycling, further enhancing the production of organic matter in the basin. This is clearly reflected by leaching of redox sensitive elements and minima in Mn concentrations. In contrast, maximum interglacial conditions resulted in a vigorous deep water circulation, well-oxygenated bottom water conditions, low TOC levels and the preservation of the redox sensitive element $\mathrm{Mn}$ in the sediment. The general lack of short-term 
variability in the Mn records is a strong evidence supporting the idea that the restricted ventilation in the SCS were primarily controlled by sea level changes and not by variations in the monsoon intensity. Otherwise, short-term variations in the monsoon circulation, as recorded in for example TOC, should have resulted in rapid excursions in the Mn content. The short-term TOC fluctuations (primarily in the precession and obliquity band) superimposed on the glacial-interglacial cycles therefore must represent primary productivity variations caused by fluctuations in the winter monsoon winds that control mixing and biological productivity.

\section{Acknowledgements}

This study is a contribution to the Taiwan IMAGES project. Curation of the IMAGES core was conducted by the Core Laboratory under the National Center for Ocean Research (NCOR). This study was supported by the National Science Council of the R.O.C. under Grant NSC 95-2116-M-002-023 to LL. LL also acknowledges financial support from Academia Sinica, Taiwan. Li Lo, Hui-Wen Chen and Hui-Fen Chen (NTU) are thanked for help with the XRF measurements. Yin-Tian Lin (IESAS) is cordially thanked for help with the $\delta^{13} \mathrm{C}_{\text {org }}$-measurements. Wen-Tzong Liang (IESAS) is thanked for help with the topographic maps of the South China Sea. The constructive comments of two anonymous reviewers greatly helped to improve our manuscript.

\section{References}

Bassinot, F.C., Labeyrie, L.D., Vincent, E., Quidelleur, X., Shackleton, N.J., Lancelot, Y., 1994. The astronomical theory of climate and the age of the Brunhes-Matuyama magnetic reversal. Earth Planet. Sci. Lett. 126, 91-108.

Betzer, P.R., Showers, W.J., Laws, E.A., Winn, C.D., Di Tullio, G.R., Kroopnick, P.M., 1984. Primary productivity and particle fluxes on a transect of the equator at $153^{\circ} \mathrm{W}$ in the Pacific Ocean. Deep-Sea Res. 31, 1-11.

Boulay, S., Colin, C., Trentesaux, A., Clain, S., Liu, Z., Lauer-Leredde, C., 2007. Sedimentary responses to the Pleistocene climatic variations recorded in the South China Sea. Quaternary Res. 68 (1), 162-172.

Boutton, T.W., 1991a. Stable carbon isotope ratios of natural materials: atmospheric, terrestrial, marine, and freshwater environments. In: Coleman, D.C., Fry, B. (Eds.), Carbon Isotope Techniques. Academic Press, San Diego, pp. 173-185.

Boutton, T.W., 1991b. Stable carbon isotope ratios of natural materials: sample preparation and mass spectrometric analysis. In: Coleman, D.C., Fry, B. (Eds.), Carbon Isotope Techniques. Academic Press, San Diego, pp. 155-172.

Bradley, R.S., 1999. Paleoclimatology: Reconstructing Climates of the Quaternary. International Geophysics Series, 68. Harcourt Academic Press, San Diego, 613 pp.

Broecker, W.S., Patzert, W.C., Toggweiler, J.R., Stuiver, M., 1986. Hydrography, chemistry, and radioisotopes in the southeast Asian basin. J. Geophys. Res. 91, 14345-14354.

Brumsack, H.-J., 2006. The trace metal content of recent organic carbon-rich sediments: implications for cretaceous black shale formation. Palaeogeogr. Palaeoclimatol. Palaeoecol. 232 (2-4), 344-361.

Bühring, C., Sarnthein, M., Erlenkeuser, H., 2004. Toward a high-resolution stable isotope stratigraphy of the last 1.1 million years: Site 1144, South China Sea. In: Prell, W.L., Wang, P., Blum, P., Rea, D.K., Clemens, S.C. (Eds.), Proceedings of the Ocean Drilling Program, Scientific Report, vol. 184. Ocean Drilling Program, Texas A\&M University, College Station, TX, pp. 1-8.

Calvert, S.E., Pedersen, T.F., Thunell, R.C., 1993. Geochemistry of the surface sediments of the Sulu and South China Seas. Mar. Geo. 114, 207-231.

Chang, C.-P. (Ed.), 2004. East Asian Monsoon. World scientific series on meteorology of East Asia, 2. World Scientific Publishing Co., Singapore, $564 \mathrm{pp}$.

Chen, M.-T., Beaufort, L., Shipboard Scientific Party of IMAGES III/MD106-IPHIS Cruise (Leg II), 1998. Exploring quaternary variability of the East Asia monsoon, Kuroshio current, and Western Pacific Warm Pool systems: high-resolution investigations of paleoceanography from the IMAGES III (MD106)-IPHIS Cruise. TAO 9 (1), 129-142.

Chen, M.-T., Huang, C.-Y., 1998. Ice-volume forcing of winter monsoon climate in the South China Sea. Paleoceanography 13 (6), $622-633$.

Chen, M.-T., Shiau, L.-J., Yu, P.-S., Chiu, T.-C., Chen, Y.-G., Wei, K.-Y., 2003. 500,0000-year records of carbonate, organic carbon, and foraminiferal sea-surface temperature from the southeastern South China Sea (near Palawan Island). Palaeogeogr. Palaeoclimatol. Palaeoecol. 197, 113-131.

Ding, Z., Liu, T., Rutter, N.W., Yu, Z., Guo, Z., Zhu, R., 1995. Ice-volume forcing of East Asian winter monsoon variations in the past 800,000 years. Quaternary Res. 44, 149-159.

Emerson, S., 1985. Organic carbon preservation in marine sediments, In: Sundquist, E.T., Broecker, W. (Eds.), CO2: Natural Variations Archean to Present. Geophysical Monographs, AGU, Washington D.C. pp. 78-87.

Gong, G.C., Liu, K.K., Liu, C.T., Pai, S.C., 1992. The chemical hydrography of the South China Seawest of Luzon and a comparison with the West Philippine Sea. TAO 3, 587-602.

Hanebuth, T., Stattegger, K., Grootes, P.M., 2000. Rapid flooding of the Sunda Shelf: a late-glacial sea-level record. Science 288, 1033-1035.

Heath, G.R., Moore, T.C.J., Dauphin, J.P., 1977. Organic carbon in deep-sea sediments. In: Andersen, N.R., Malahoff, A. (Eds.), The Fate of Fossil Fuel $\mathrm{CO}_{2}$ in the Oceans. Plenum Press, New York, pp. 605-625.

Higginson, M.J., Maxwell, J.R., Altabet, M.A., 2003. Nitrogen isotope and chlorin paleoproductivity records from the Northern South China Sea: remote vs. local forcing of millennial- and orbital-scale variability. Mar. Geo. 201, 223-250. 
Huang, C.-Y., Wu, S.-F., Zhao, M., Chen, M.-T., Wang, C.-H., Tu, X., Yuan, P.B., 1997. Surface Ocean and monsoon climate variability in the South China Sea since the last glaciation. Mar. Micropaleontol. 32, 71-94.

Ibach, L.E.J., 1982. Relationship between sedimentation rate and total organic carbon content in ancient marine sediments. Am. Assoc. Petrol. Geol. Bull. 66, 170-183.

Ingall, E.D., van Capellen, P., 1990. Relation between sedimentation rate and burial of organic phosphorus and organic carbon in marine settings. Geochim. Cosmochim. Acta 54, 373-386.

Jacob, L., Emerson, S., Huested, S.S., 1987. Trace metal geochemistry in the Cariaco Trench. Deep-Sea Res. 34, $965-981$.

Jakobsson, M., Løvlie, R., Al-Hanbali, H., Arnold, E., Backman, J., Mörth, M., 2000. Manganese and color cycles in Arctic Ocean sediments constrain Pleistocene chronology. Geology 28, 23-26.

Jian, Z., Wang, L., Kienast, M., Sarnthein, M., Kuhnt, W., Lin, H.-L., Wang, P., 1999. Benthic foraminiferal paleoceanography of the South China Sea over the last 40,000 years. Mar. Geo. 156, 159-186.

Jian, Z., Wang, P., Chen, M.-P., Li, B., Zhao, Q., Bühring, C., Laj, C., Lin, H.-L., Pflaumann, U., Bian, Y., Wang, R., Cheng, X., 2000. Foraminiferal responses to major Pleistocene paleoceanographic changes in the southern South China Sea. Paleoceanography 15 (2), 229-243.

Kienast, M., Steinke, S., Stattegger, K., Calvert, S.E., 2001a. Synchronous tropical South China Sea SST change and Greenland warming during deglaciation. Science 291, 2132-2134.

Kienast, M., Calvert, S.E., Pelejero, C., Grimalt, J.O., 2001b. A critical review of marine sedimentary $\delta^{13} C_{o r g}-p C_{2}$ estimates: new palaeorecords from the South China Sea and a revisit of other low-latitude $\delta^{13} \mathrm{C}_{\text {org }}-p \mathrm{CO}_{2}$ records. Global Biogeochem. Cycles 15 (1), 113-127.

Kutzbach, J.E., 1981. Monsoon climate of the early Holocene: climate experiment with the earth's orbital parameters for 9000 years ago. Science 214 (4516), 59-61.

Laskar, J., Joutel, F., Boudin, F., 1993. Orbital, precessional, and insolation quantities for the Earth from $-20 \mathrm{Myr}$ to $+10 \mathrm{Myr}$. Astron. Astrophys. 270, 522-533.

Lee, T.-Q., 2000. Geomagnetic secular variation of last one million years recorded in core MD972142 from southeastern South China Sea. J. Geol. Soc. China 43 (3), 423-434.

Lee, M.-Y., Wei, K.-Y., 2000. Australasian microtectites in the South China Sea and the West Philippine Sea: implications for age, size, and location of the impact crater. Meteorit. Planet. Sci. 35, 1151-1155.

Li, L., Qu, T., 2006. Thermohaline circulation in the deep South China Sea basin inferred from oxygen distributions. J. Geophys. Res. 111 (C05017), doi:10.1029/2005JC003164.

Liang, W.-D., Jan, J.-C., Tang, T.-Y., 2000. Climatological wind and upper ocean heat content in the South China Sea. Acta Oceanogr. Taiwan. 38, 91-114.

Lin, H.-L., 2003. Late Quaternary deep-water circulation in the South China Sea. TAO 14 (3), $321-333$.

Lin, H.-L., Lai, C.-T., Ting, T.-C., Wang, L.-J., Sarnthein, M., Hung, J.-J., 1999. Late Pleistocene sea surface nutrient in the South China Sea: Cd/Ca records of planktonic foraminifera. Mar. Geo. 156, 197-210.

Liu, K.-K., Chao, S.-Y., Shaw, P.-T., Gong, G.-C., Chen, C.-C., Tang, T.Y., 2002. Monsoon-forced chlorophyll distribution and primary production in the South China Sea: observations and a numerical study. Deep-Sea Res.: I 49, $1387-1412$.

Löwemark, L., Lin, H.-L., Sarnthein, M., 2006. Temporal variations of the trace fossil Zoophycos in a 425 k.y.-long sediment record from the South China Sea: implications for the ethology of the Zoophycos-producer. Geol. Mag. 143 (1), 105-114.

Löwemark, L., Jakobsson, M., Mörth, M., Backman, J., 2008. Arctic Ocean Mn contents and sediment color cycles. Polar Res. 27, 105-113.

Mangini, A., Jung, M., Laukenmann, S., 2001. What do we learn from peaks of uranium and of manganese in deep sea sediments? Mar. Geo. 177 (1/2), 63-78.

Martinson, D.G., Pisias, N.G., Hays, J.D., Imbrie, J., Moore, T.C., Shackelton, N.J., 1987. Age dating and the orbital theory of the ice ages: development of a high-resolution 0-300,000-year chronostratigraphy. Quaternary Res. 27, 1-29.

Minakawa, M., Noriki, S., Tsunogai, S., 1996. Manganese in the East China Sea and the Yellow Sea. Geochem. J. $30,41-55$.

Müller, P.J., Suess, E., 1979. Productivity, sedimentation rate, and sedimentary organic matter in the oceans. I. Organic carbon preservation. Deep-Sea Res. 26A, 1347-1362.

Müller, P.J., Erlenkeuser, H., von Grafenstein, R., 1983. Glacial-interglacial cycles in oceanic productivity inferred from organic carbon contents in eastern North Atlantic sediment cores. In: Thiede, J., Suess, E. (Eds.), Coastal Upwelling, Its Sediment Record. Part B. Sedimentary records of ancient coastal upwelling. NATO Conference Series IV, Marine Science. Plenum Press, New York, NY, United States, pp. 365-398.

Obata, H., Doi, T., Hongo, Y., Alibo, D.S., Minami, H., Kato, Y., Maruo, M., 2007. Manganese, cerium and iron in the Sulu, Celebes and Philippine Seas. Deep-Sea Res.: Part II. Top. Stud. Oceanogr. 54 (1/2), 38-49.

Oppo, D.W., Linsley, B.K., Rosenthal, Y., Dannenmann, S., Beaufort, L., 2003. Orbital and suborbital climate variability in the Sulu Sea, western tropical Pacific. Geochem. Geophys. Geosyst. 4 (1).

Pelejero, C., 2003. Terrigenous n-alkane input in the South China Sea: high-resolution records and surface sediments. Chem. Geol. 200, 89-103.

Qu, T., 2002. Evidence of water exchange between the South China Sea and the Pacific through the Luzon Strait. Acta Oceanol. Sin. 21, 175-185.

Qu, T., Du, Y., Meyers, G., Ishida, A., Wang, D., 2005. Connecting the tropical Pacific with Indian Ocean through South China Sea. Geophys. Res. Lett. 32 (24), L24609, doi:org/10.1029/2005GL024698.

Qu, T., Girton, J.B., Whitehead, J.A., 2006a. Deepwater overflow through Luzon Strait. J. Geophys. Res. 111, C01002, doi:10.1029/2005JC003139.

Qu, T., Du, Y., Sasaki, H., 2006b. South China Sea throughflow: a heat and freshwater conveyor. Geophys. Res. Lett. 33, L23617, doi:10.1029/2006GL028350.

Rosenthal, Y., Oppo, D.W., Linsley, B.K., 2003. The amplitude and phasing of climate change during the last deglaciation in the Sulu Sea, western equatorial Pacific. Geophys. Res. Lett. 30 (8).

Sarnthein, M., Winn, K., Duplessy, J.-C., Fontugne, M.R., 1988. Global variations of surface ocean productivity in low and mid latitudes: influence on $\mathrm{CO}_{2}$ reservoirs of the deep ocean and atmosphere during the last 21,000 years. Paleoceanography 3 (3), 361-399. 
Sarnthein, M., Pflaumann, U., Wang, P., Wong, H.K., 1994. Preliminary report on SONNE-95 cruise 'Monitor Monsoon' to the South China Sea, Berichte-Reports. Geologisch-Paläontologisches Institut der Universität Kiel 68, 1-229.

Schultz, H.D., Zabel, M. (Eds.), 2000. Marine Geochemistry. Springer, Berlin, p. 455.

Shackleton, N.J., Sánchez-Goñi, M.F., Paillerc, D., Lancelot, Y., 2003. Marine Isotope Substage 5e and the Eemian Interglacial. Global Planet. Change 36, 151-155.

Shiau, L.-J., Yu, P.-S., Wei, K.-Y., Yamamoto, M., Chen, M.-T., 2008. Sea surface temperature, productivity, and terrestrial flux variations of the southeastern South China Sea over the past 800,000 years (IMAGES MD972142). TAO 19 (4), doi:10.3319/TAO.2008.19.4.363.

Smith, W.H.F., Sandwell, D.T., 1997. Global sea floor topography from satellite altimetry and ship depth soundings. Science 277 (5334), 1956-1962.

Steinke, S., Kienast, M., Pflaumann, U., Weinelt, M., Stattegger, K., 2001. A high resolution sea-surface temperature record from the tropical South China Sea (16,500-3000 yr B.P). Quaternary Res. 55 (3), 352-362.

Steinke, S., Kienast, M., Hanebuth, T., 2003. On the significance of sea-level variations and shelf paleo-morphology in governing sedimentation in the southern South China Sea during the last deglaciation. Mar. Geo. 201, 179-206.

Sun, X., Li, X., Beug, H.-J., 1999. Pollen distribution in hemipelagic surface sediments of the South China Sea and its relation to modern vegetation distribution. Mar. Geo. 156 (1-4), 211-226.

Tamburini, F., Adatte, T., Föllmi, K., Bernasconi, S.M., Steinmann, P., 2003. Investigating the history of East Asian monsoon and climate during the last glacial-interglacial period (0-140000 years): mineralogy and geochemistry of ODPSites 1143 and 1144, South China Sea. Mar. Geo. 201, 147-168.

Thompson, P.R., Bé, A.W.H., Duplessy, J.C., Shackleton, N., 1979. Disappearance of pink-pigmented Globigerinoides ruber at 120,000 yr BP in the Indian and Pacific Oceans. Nature 280, 554-558.

Thunell, R.C., Miao, Q., Calvert, S.E., Pedersen, T.F., 1992. Glacial-Holocene biogenic sedimentation patters in the South China Sea: productivity variations and surface water $\mathrm{pCO}_{2}$. Paleoceanography 7 (2), 142-163.

Tian, J., Wang, P., Cheng, X., 2004. Development of the East Asian monsoon and Northern Hemisphere glaciation: oxygen isotope records from the South China Sea. Quat. Sci. Rev. 23, 2007-2016.

Tyson, R.V., 1995. Sedimentary Organic Matter. Chapman and Hall, London, p. 615.

Tyson, R.V., 2001. Sedimentation rate, dilution, preservation and total organic carbon: some results of a modelling study. Org. Geochem. 32, 333-339.

van Santvoort, P.J.M., De Lange, G.J., Thomson, J., Cussen, H., Wilson, T.R.S., Krom, M.D., Ströhle, K., 1996. Active post-depositional oxidation of the most recent sapropel (S1) in sediments of the eastern Mediterranean Sea. Geochim. Cosmochim. Acta 60 (21), 4007-4024.

Waelbroeck, C., Labeyrie, L., Michel, E., Duplessy, J.C., McManus, J.F., Lambeck, K., Balbon, E., Labracherie, M., 2002. Sea-level and deep water temperature changes derived from benthic foraminifera isotopic records. Quat. Sci. Rev. 21, 295-305.

Wang, B. (Ed.), 2006. The Asian Monsoon. Springer, p. 787.

Wang, L., Sarnthein, M., Erlenkeuser, H., Grimalt, J., Grootes, P., Heilig, S., Ianova, E., Kienast, M., Pelejero, C., Pflaumann, U., 1999. East Asian monsoon climate during the Last Pleistocene: high-resolution sediment records from the South China Sea. Mar. Geo. 156, 245-284.

Wehausen, R., Brumsack, H.-J., 2002. Astronomical forcing of the East Asian monsoon mirrored by the composition of Pliocene South China Sea sediments. Earth Planet. Sci. Lett. 201 (3/4), 621-636.

Wehausen, R., Tian, J., Brumsack, H.-J., Cheng, X., Wang, P., 2003. Geochemistry of Pliocene sediments from ODP Site 1143 (southern South China Sea). In: Prell, W.L., Wang, P., Blum, P., Rea, D.K., Clemens, S.C. (Eds.), Proceedings of the Ocean Drilling Program, Scientific Report, 184. Ocean Drilling Program, Texas A\&M University, College Station, TX, pp. 1-25.

Wei, K.-Y., Chiu, T.-C., Chen, Y.-G., 2003. Toward establishing a maritime proxy record of the East Asian summer monsoons for the late Quaternary. Mar. Geo. 201, 67-79.

Wei, G., Liu, Y., Li, X.-h., Shao, L., Fang, D., 2004. Major and trace element variations of the sediments at ODP Site 1144, South China Sea, during the last $230 \mathrm{ka}$ and their paleoclimate implications. Palaeogeogr. Palaeoclimatol. Palaeoecol. 212 (3/4), 331-342.

Wei, G.-J., Huang, C.-Y., Wang, C.-C., Lee, M.-Y., Wei, K.-Y., 2006a. High-resolution benthic foraminifer $\delta^{13}$ C records in the South China Sea during the last $150 \mathrm{ka}$. Mar. Geo. 232 (3/4), 227-235.

Wei, G., Li, X.-H., Liu, Y., Shao, L., Liang, X., 2006b. Geochemical record of chemical weathering and monsoon climate change since the early Miocene in the South China Sea. Paleoceanography 21, PA4214, doi:10.1029/2006PA001300.

Whitmore, T.C., 1975. Tropical Rain Forests of the Far East. Clarendon Press, Oxford, 282 pp.

Wyrtki, K., 1961. Physical oceanography of the south-east Asian waters. NAGA Report, vol.2. Scientific Results of Marine Investigations of the South China Sea and the Gulf of Thailand. Scripps Institution of Oceanography, La Jolla, CA, 195 pp.

Yamagata, T., Masumoto, Y., 1989. A simple ocean-atmosphere coupled model for the origin of a warm El Nino southern oscillation event. Philos. Trans. R. Soc. Lond. A329, 225-236.

Yancheva, G., Nowaczyk, N.R., Mingram, J., Dulski, P., Schettler, G., Negendank, J.F.W., Liu, J., Sigman, D.M., Peterson, L.C., Haug, G.H., 2007. Influence of the intertropical convergence zone on the East Asian monsoon. Nature 445 (7123), 74-77.

Zhao, M., Huang, C.-Y., Wang, C.-C., Wei, G., 2006. A millennial-scale U37K' sea-surface temperature record from the South China Sea $\left(8^{\circ} \mathrm{N}\right)$ over the last $150 \mathrm{kyr}$ : monsoon and sea-level influence. Palaeogeogr. Palaeoclimatol. Palaeoecol. 236 (1/2), 39-55. 